\title{
A Comparative Study on Contribution of Governance on Economic Growth in the East African Community Countries
}

\author{
Joseph Abuga Orayo \\ Head of Monitoring \\ Evaluation and Research Unit Meru County \\ Department of Health \\ Kenya \\ E-mail: josabu2008@gmail.com \\ George N. Mose \\ Lecturer at Faculty of Arts and Social Sciences \\ Kisii University \\ Nairobi, Kenya
}

Received: August 5, 2016 Accepted: September 10, 2016 Published: September 13, 2016

doi:10.5296/ijrd.v3i2.9848 URL: http://dx.doi.org/10.5296/ijrd.v3i2.9848

\begin{abstract}
This study sought to explore the relationship between good governance and economic growth among the East Africa Community (EAC) countries. The study utilized panel data to analyse six major World Bank governance indicators namely: Voice and Accountability, Political Stability and Absence of Violence, Government Effectiveness, Regulatory Quality, Rule of Law and Control of Corruption effect on economic growth in the respective country and region for the period 1999-2013. The Random effect model (REM) and Ordinary Least Square (OLS) estimation techniques were employed for comparative analysis. The study showed that among the governance indicators, political stability, quality regulatory and control of corruption were significant. The first two indices were negatively related to economic growth rate while the latter was positively related to economic growth rate. From the OLS models, voice and accountability had a significant effect on economic growth rate in Kenya and Uganda. The quality of regulation had significant effect in Kenya and Tanzania while rule of law was found to be significant only in Kenya. The study suggests that in order
\end{abstract}


to advance the economic performance in EAC countries, the EAC states need to invest in more effective regulation on both public and private institutions to enhance social, political and sustainable economic interactions. Similarly, the government needs to encourage national cohesion and peaceful co-existence that would foster political stability and reduce violence. By investing in good governance through establishment of key institutions of governance are likely to spur economic growth.

Keywords: Governance, Economic Growth, East Africa Community, Ordinary Least Squares and Random Effects Model

\section{Introduction}

Good governance has been touted as one of the emerging factors that are central to economic growth in developing countries (Fayissa and Nsiah, 2010). The term governance has a wide range of meaning depending on the context in which it is applied. According to the World Bank (1994) "governance" is defined as the "manner in which power is exercised in the management of a country's social and economic resources for development". Kaufmann, (2005) further looks at governance in three dimensions: political dimension-process by which those in authority are selected monitored and replaced; economic dimension-the government's capacity to effectively manage its resources and implement sound policies and institutional respect dimension-the respect of citizens and the state for the country's institutions.

The other broad governance issue is hinged on the concepts of democracy and the rule of law, respect for the human rights which are universally accepted as well as judicial independence. Further participation in the conduct of public affairs by the citizenry, electoral integrity, political plurality, freedom of expression and the independence of media allowing for free access to information held by public bodies are integral to effective participation and increased empowerment of the citizenry. While literature gives diverse definitions of the term 'governance', there is agreement about its dimensions and in particular, public governance is linked with how governments are structured, what processes they use in governing and what results they are able to accomplish for the people they govern.

Good governance is at the core of the framework of fiscal prudence, proper utilization of resources in public domain and a system which is accountable. Good governance mitigates on corruption and rent seeking tendencies which ensure resources are efficiently and effectively applied in pursuit of economic development in the country (Wohlmuth, 1999). Similarly, good governance promotes human rights, empowers citizenry and ensures democratic principle are respected and promoted. This creates conducive environment for donor support and generates investors' confidence both local and foreign leading to economic growth. Another aspect which interfaces with good governance is the donor assistance conditionalities and foreign direct investment. Good governance has for the better part of the last three decades been affirmed as conditionality for most external assistance by development partners such as the World Bank and International Monetary Fund (IMF).

Similarly, the African Union (AU) underscores the importance of good governance through initiatives such as New Partnership for Africa's Development (NEPAD) whose objectives 
include principles of a commitment to good governance, democracy, human rights and conflict resolution that are associated to the creation of an environment conducive to investment and long-term economic growth. Further, evolution of information, communication and Technology (ICT) including use of the Internet, mobile phones and social media have in the recent past been central in the transformation of governance in a number of countries specifically in the northern Africa some leading regime change or alteration of the balance of power between the people and the state.

\subsection{Economic Performance of East African Community (EAC) Countries}

The EAC comprises of five countries including the republic of Kenya, Tanzania, Uganda, Rwanda and Burundi (EAC, 2013). The EAC aims at widening and deepening cooperation among the partner states for political, economic and social benefits. All the member states have gone through turbulent situations at different times in their history which have impacted significantly on their economies an aspect which triggered the tenets of governance that has been tested over time in these countries. A review of economic performance for the EAC countries shows erratic and inconsistent trends. Rwanda has had the most impressive average growth rate in the past decade at 8.5 percent followed by Uganda and Tanzania at 6.9 and 6.0 percent respectively. Kenya 's growth rate has been low at 3.5 percent on average in the review period while Burundi has the worst record at 1.7 percent lower than the world average and Sub-Saharan countries average growth rates of 2.8 and 4.3 percent respectively. The trends observed in figure 1 shows that Rwanda has had the highest growth rate 12.5 and 13.8 percent in the year 1996 and 1997 respectively while Burundi has growth rate of -8 and -1.59 in the same period. Among the five countries, Uganda and Tanzania has had the most consistent growth oscillating between 4 and 10 percent. Burundi has the most significant positive change moving from negative 8 percent to 5.12 percent between 1996 and 2006 and 3.9 percent in 2010 .

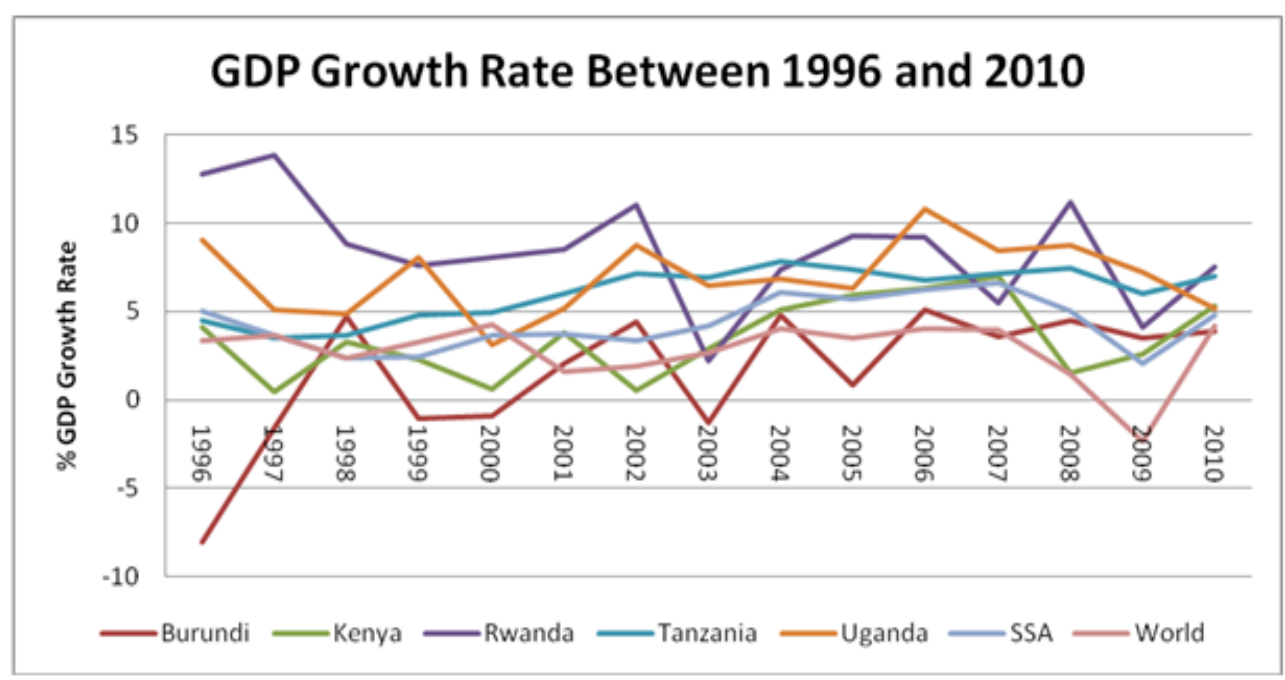

Figure 1. Trends of Economic Growth Rate for the Period 1996-2010

Source: Own graph based on data from World Bank. 


\subsection{Governance Trends in East African Community (EAC) Countries}

Many African countries in general and EAC countries in particular have consistently been ranked poorly on governance indicators across the broad spectrum. The six governance indicators include; first, the voice and accountability: measures the level of a country's citizen participation in the selection of government, as well as freedom of expression, association and of the press; secondly, the political stability and absence of violence which: measures the perceived likelihood of destabilizing the government by unconstitutional or violent means; thirdly, the government effectiveness: measures the quality of public services, performance and independence of the civil service; the quality of development and implementation of policies; and the credibility of government's commitment; fourthly, the quality of regulation: this measures the ability of government to develop and implement sound policies and regulations conducive to private sector development; fifthly, rule of law: measures citizens' degree of confidence in societal rules and their compliance with these rules and, in particular, respect for contracts, powers of the police and courts, and perception of crime and violence. Lastly, control of corruption: this measures the use of public positions for private gain, including petty and grand corruption, as well as the elite and private interests taking the state hostage. A review of the six indicators of governance stipulated by World Bank is measured on a scale of -2.5 which is poorly governed to 2.5 for well governed countries.

On voice and accountability, Burundi in 1996 was the worst ranked among the five countries at negative 1.75 followed by Rwanda at -1.56 while Kenya at -0.67 was the highest ranked. The trend is sustained for Burundi and Rwanda up to 2000 and is reversed in 2002 with Rwanda ranking worst at -1.47 and Burundi at -1.24 . Tanzania has been the best performing in this category improving from -0.74 to -0.11 a massive 84.84 percent increase. Uganda has been the most unstable with erratic fluctuations while Rwanda registers a reversal of gains from 2005 to the year 2011. Similarly, political stability and absence of violence like in voice and accountability, Uganda, Rwanda and Burundi were ranked lowest among the five countries in 1996 at $-1.61,-1.95$ and -2.24 respectively while Kenya and Tanzania were ranked highest at -0.74 and -0.71 respectively. In 1998 all the countries with exception of Tanzania deteriorated. Rwanda improved drastically from a low of -2.15 in 1998 to -0.05 while Kenya displays converse performance from -0.74 to -1.31 over the same review period. Tanzania had the best ranking at -0.01 in the year 2011 with Burundi having the worst at -1.81 .

Effective government is essential for promoting private ventures, reducing bureaucracy and spurring economic activities. Among the five countries, Tanzania and Uganda have consistently been the most effective while Burundi has been most ineffective. Rwanda made the most gains from -1.2 in 1996 to reach -0.07 in 2011 while Kenya depicts reversal from -0.34 to -0.054 over the same period. Consistent with all other indicators, Burundi ranks lowest at -1.67 with Uganda ranking best at -0.20 in 1996 on Regulatory Quality (RQ). All countries with exception of Uganda improved in 1998 with Burundi posting highest change. The best score is by Uganda in 2003 and 2004 at 0.00 while Rwanda is the most improved from -147 to -0.12 while Tanzania is the only country that showed reversal in 1996 as 
compared to 2011. Kenya and Uganda seems to have the best regulatory framework over the review period.

On the Rule of Law (RL), Rwanda had the worst ranking followed by Burundi at -1.73 and -1.72 respectively in reviewed period. The indicator is also the worst for Kenya among the six indicators in the year 1996 at -1.04 while it is the best for Tanzania at -0.25 . Rwanda is the most improved at 82.34 percent followed by Uganda at 38 percent. Tanzania on the other hand had a worsening record deteriorating by 103 percent from -0.25 to -0.52 score. Finally, control of corruption, entails rent seeking resulting to low levels of employment, high cost of goods and services as producers pass on the cost of corruption to consumers resulting in reduced consumption and overall poor economic performance. Among the five countries, Uganda was ranked the least corrupt in 1996 at -0.6 while Burundi was ranked most at -1.39 . This is however not sustained as Uganda ranking worsens in subsequent years reversing the gains to have a score of -0.92 in 1998, -0.91 in 2009 and -0.86 in 2011 . Rwanda had the best ranking in the year 2007 at 0.01 which improved to reach 0.45 in the year 2011, a whopping 148 percent positive change.

Based on the six reviewed governance indicators,(i.e. Corruption, poor human rights record, rule of law, low accountability and transparency in the public sector and poor public involvement in running the affairs of the nation coupled with electoral malpractices) the five member states of EAC in particular have consistently been ranked poorly across the spectrum. These countries are putting huge resources on governance improvements through establishment of key institution of governance but with little gains on economic growth rates, begging the question if the reforms are giving returns commensurate to the funding.

Thus this paper intends not only to investigate the nexus between economic growth and governance but also undertake a comparative analysis with a view of laying salient grounds for a case of evidence based application of specific reforms in institutional framework of not just the countries in question but across the globe.

Studies both theoretical and empirical conclusively submit on the relevance of good governance as an impetus for economic growth. The Harrod-Domar Model lay a lot of emphasis on investment to boost economic growth because it argues that investment will not only create the much needed income but it will also aid in the increase of capital stock, the two most important ingredients of any meaningful economic growth process. On the other hand, the Solow model of long- Run Growth assumes that labour and capital are substitutable in the production function thus making the entire production process adjustable. In the long run the rate of economic growth is determined by expanding labour force and technical progress. Finally, Kaldor's Growth Model focuses more into the role of technical progress in the process of capital accumulation and productivity. The model operates under two main conditions namely; constant working population and expanding population which enables the model to analyse growth especially in the developing countries. However, the endogenous growth theories have elaborately introduced research and development, technology and governance issues as central factors in achieving faster economic growth and development. In this case, governance was shown to play facilitative role of promoting technological advances and reducing barriers to investment through a responsive bureaucracy (King \& Rebelo, 1990; North, 2005). Institutional reforms and good capacity creates structures that protect the 
individual rights and this boosts the levels of investment which creates a conducive environment of economic flourishing.

Further, a number of countries have in the recent years made efforts to improve key governance institutions, reformed public institutions and promoted laws intended to foster good governance. The urge for changes and public sector reforms has a significant impact on the overall fiscal management in the country with a huge portion of the funds devoted to making them operational. As Fosu et al. (2006) observe, although improved economic outcomes may be realised from more politically accountable governments, economically desirable policies are often not pursued if they pose political risks or are unpopular with the citizens. This study therefore seeks to find evidence if any on how funding good governance initiatives pays back through economic development.

The study enriches existing studies and offers a more specific angle through a review of the five EAC countries by undertaking a panel study. This will provide a prudent and credible justification for the enormous resources that are devoted to governance institution and therefore ensure that the mainstreaming of good governance in the development agenda of the countries is factually supported by policy makers.

\section{Literature Review}

Economic growth theories have for a long time profoundly differed on what variables triggers economic growth. Some of the classical economists have argued that the role of governments is minimal while others contend clear requirement in correcting market imperfections and boosting the economy during recession. This view is propagated by other economists who also posit that governments are indispensable when it comes to economic activities.

There is substantive empirical literature providing evidence that good governance is growth enhancing and affects other development conditions such as poverty and inequality reduction. For example a study by Chauvet and Collier (2004) found that countries that suffered from poor governance, on average, experienced 2.3 percentage points less GDP growth per year compared to other developing countries. The quality of governance as captured in most studies emphasizes the quality of institutional development mainly depicted by rule of law, political freedom and stability as well as civil liberties and human rights. Hall and Jones (1999) attribute differences in governance and institutions among countries to much of the differences in productivity hence output per worker. A study by Rowley (1999) reveals high levels of rent seeking and rent extraction deeply rooted in the colonial structures sustained after independence. Using examples of Kenya, Ghana, Nigeria and the Democratic Republic of Congo the study concluded that existing policies, structures and lack of constitutionally guaranteed property rights in these countries avail space for rent-extraction which results to misallocation of public resources. Governance relevance in development outcomes is supported by Kaufmann, et al. (1999) who concludes that development is anchored to a one-standard rise of one of the six indicators of governance. On the other hand, Chong and Calderon (2000) concluded that poor institutions and income inequality reinforce each other irrespective of the political considerations and the political stability indicator hugely influences inequality aspects. 
In the Philippines, Azfar and Gurgur (2005) found that communities with higher levels of perceived corruption experienced worse health and education indicators while Quibria (2006) validates this relationship between governance and growth in Asia. It was revealed that there existed a positive relationship between the governance score and per capita real GDP for all six dimensions in 1998 and 2008. However, in 2008, the correlation between governance indicators and per capita real income remained more or less the same whereas government effectiveness remained the most highly correlated; political stability, and voice and accountability remained the least correlated with the income level. Akpan and Effiong, (2012) revealed a significance relationship between governance indices (rule of law, regulatory quality as well as the political stability) and per capita growth. A study by Kagundu (2006), finds positive and statistically significantly effect of governance on growth.

The study employs panel data set from 100 sample countries covering the period between 1971 and 2000. Based on cross section data from 71 economies, Cooray, (2009) concluded that increased Public Expenditure (PE) and good governance foster economic growth outcomes. The study incorporated both the size and the quality dimensions of government Similarly, Prichett (1996) and Rajkumar and Swaroop (2002) hold a common position. Their findings affirmed that improving the efficacy of public capital can result to improved growth and countries with good governance make more effective use of PE and further increased PE results to improved governance. Therefore, as depicted from both theoretical and empirical literature, the clear cut role of governance on economic growth remains inconclusive. Little though has been tackled as far as comparative analysis is concerned. Most of the studies have largely concluded that good governance arguments growth. One lingering issue however is the causality aspect since good governance may be a product of growth. From the review, existing studies are inconclusive in making the debate on the role of governance in fostering economic growth far from over and hence basis for this study.

\section{Data and Methodology}

The study used secondary data covering the period between 1999 and 2013. The choice of duration is informed by data availability especially for the governance variables and the fundamental governance changes which has occurred within the study period. Data used on the six governance indicators are published by a team at the World Bank. The presented methodology for constructing these variables as described by Kauffman et al. (2009) have a great ability to positively influence the business environment and lead to lower risk in the country. They take the values of -2.5 to 2.5 , with higher levels indicating greater efforts for good governance.

\subsection{Model Specification}

The study adopted and modified a model used by Bouoiyour and Naimbayel (2010) and incorporated variables used by Kagundu, (2006) based on the Solow growth model. The econometric model of analysis is based on dynamic panel model with both cross sectional and time series components. The functional model to be estimated is presented as follows;

$$
\text { GDPRATE }_{\mathrm{i}, \mathrm{t}}=\beta_{0}+\beta_{1} \mathrm{GOV}_{\mathrm{i}, \mathrm{t}}+\beta_{2} \text { POPRATE }_{\mathrm{i}, \mathrm{t}}+\beta_{3} \text { GFCFRATE }_{\mathrm{i}, \mathrm{t}}+\beta_{4} \mathrm{INFRATE}_{\mathrm{i}, \mathrm{t}}+
$$


Where;

GDPRATE $=$ GDP per capita growth rate, GOV represents the governance indicators which include VA, PS, GE, RQ, RL, RC and CC), POPRATE= Annual average population growth rate, GFCFRATE $=$ Gross fixed capital formation (the average rate of investment) as a percentage of GDP, INFRATE $=$ Inflation rate, OPEN $=$ openness-the total volume of trade (sum of exports and imports divided by GDP).

$\beta_{\mathrm{j}}, \mathrm{j}=1,2, \ldots$ and 5 are parameters to be estimated and $\varepsilon=$ random error term

\subsection{Estimation Technique and Associated Issues}

The study uses a panel data estimation technique because of its several advantages over both cross-section and time-series data sets. The technique has greater degrees of freedom and less multi-collinearity leading to more efficient estimates, (Hsiao, 2003) and gives greater flexibility in modeling differences in behavior across countries which enables us to control for unobserved heterogeneity. In model selection, we compared fixed effects and random effects where the former assumes that the real effect size is the same in all five countries and the summary effect is our estimate of this common effect size while the latter assumes that the true effects size varies from one country to another and that the countries under study represents a random sample of effects size that could have been observed and thus the summary effect is our estimate of the mean of these effects. Further, Borenstein (2009) suggests that under fixed effects, there is an assumption that all the dispersion in observed effect is due to sampling error whereas under random effects, there is allowance that some of the dispersion observed may illustrate real differences in effect size across countries. In order to determine the best fitting model, the study adopted Hausman specification test where the fixed effects model specification was compared to the random effects model. The null hypothesis was that the differences in coefficients are not systematic. The pre estimation tests carried include; multi-collinearity and unit root. To avoid change of the estimates over time due to non stationarity, the study applied Levin-Lin-Chu unit-root test for every variable under study to avoid spurious estimates. This reduced the number of periods to fourteen. The specified model was estimated using statistical programme (STATA) and the study objects are investigated through systematic tests.

\section{Results and Discussions}

A comprehensive technical and fundamental analysis using random effects model has been undertaken in this section to establish the effect of varied specific parameters on economic growth in East African countries. According to Table 1, the GDP growth rate and the population rate have the means of 2.432 and 3.02 respectively. All the governance indices have got negative means whereby PS and RQ having the least and highest respectively. The other macroeconomic variables like inflation rate and openness of the economy have the means of 9.7 and 48.7 respectively. 
Table 1. Summary statistics

\begin{tabular}{llllll}
\hline VARIABLE & MEAN & STD. DEV. & MIN & MAX & OBS \\
\hline GDPRATE & 2.432 & 2.943 & -9.2 & 10.6 & $\mathrm{~N}=75$ \\
VA & -0.747 & 0.460 & -1.750 & -0.107 & $\mathrm{~N}=75$ \\
PS & -1.097 & 0.645 & -2.516 & 0.057 & $\mathrm{~N}=75$ \\
GE & -.650 & 0.391 & -1.727 & 0.065 & $\mathrm{~N}=75$ \\
RQ & -0.516 & 0.457 & -1.673 & 0.250 & $\mathrm{~N}=75$ \\
RL & -0.778 & 0.404 & -1.731 & -0.148 & $\mathrm{~N}=75$ \\
CC & -0.750 & 0.436 & -1.462 & 0.655 & $\mathrm{~N}=75$ \\
POPRATE & 3.023 & 1.093 & 1.2 & 10.3 & $\mathrm{~N}=75$ \\
GFCRATE & 20.283 & 6.811 & 3 & 39 & $\mathrm{~N}=75$ \\
INF & 9.652 & 6.081 & -1.4 & 28.2 & $\mathrm{~N}=75$ \\
OPEN & 48.733 & 15.544 & 22 & 81 & $\mathrm{~N}=75$ \\
\hline
\end{tabular}

Voice and accountability (VA), Political stability and absence of violence (PS), Government Effectiveness (GE), Quality of regulation (RQ), Rule of law (RL) and control of corruption (CC).

Source: Authors computation.

\subsection{Trend Analysis}

This involves the nature of fluctuations of the parameters in different countries under study. The study adopted diverse graphical illustrations in demonstrating the trend of all the variables of interest over the entire time periods across the panels. Figure 2 shows more fluctuations in Burundi which were biased below the overall mean of 2.4 whereas Rwanda, Tanzania and Uganda illustrated sporadic movements above and around the mean. Kenya showed exceptional movements which can be termed as fairly balanced around the mean. The least GDP rate was exhibited by Burundi at about $-9.7 \%$ against the highest GDP rate in Rwanda which was about 10.6 compared to other countries.

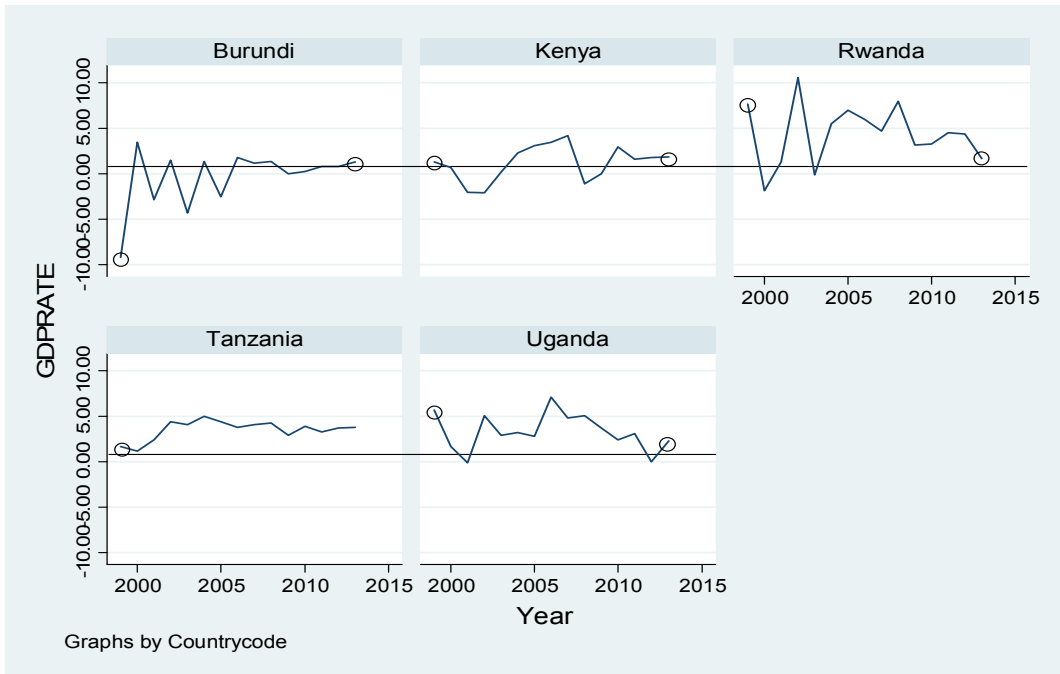

Figure 2. Trends in economic growth rate per country 


\section{Macrothink}

From the governance indices in Figure 3 below, Burundi showed poor governance in most of the indicators. Except for voice accountability which from the year 2005 to about 2010 was above zero, the rest were below zero indicating improved governance. In the Kenya case, most indices except political stability demonstrated improved governance similar to Rwanda, where most indices showed a change in the year 2005. Control of corruption in Rwanda showed improvement over the study period. However, other indices like quality of regulatory, rule of law and political stability showed poor governance levels from the beginning of the study period to the years 2002, 2003 and 2005 respectively from which governance improved continuously until the end of the study period. Unfortunately, voice accountability remained poor throughout the study period.

Unlike the case of Burundi, Tanzania illustrated improved governance since most of the governance indicators were positive although they did not hit the target of 2.5 which was a threshold as expected. This situation was similar to Uganda which had only one governance index that is political stability trending below zero indicating poor state. On overall, Kenya, Rwanda, Tanzania and Uganda had better or improved governance compared to Burundi.
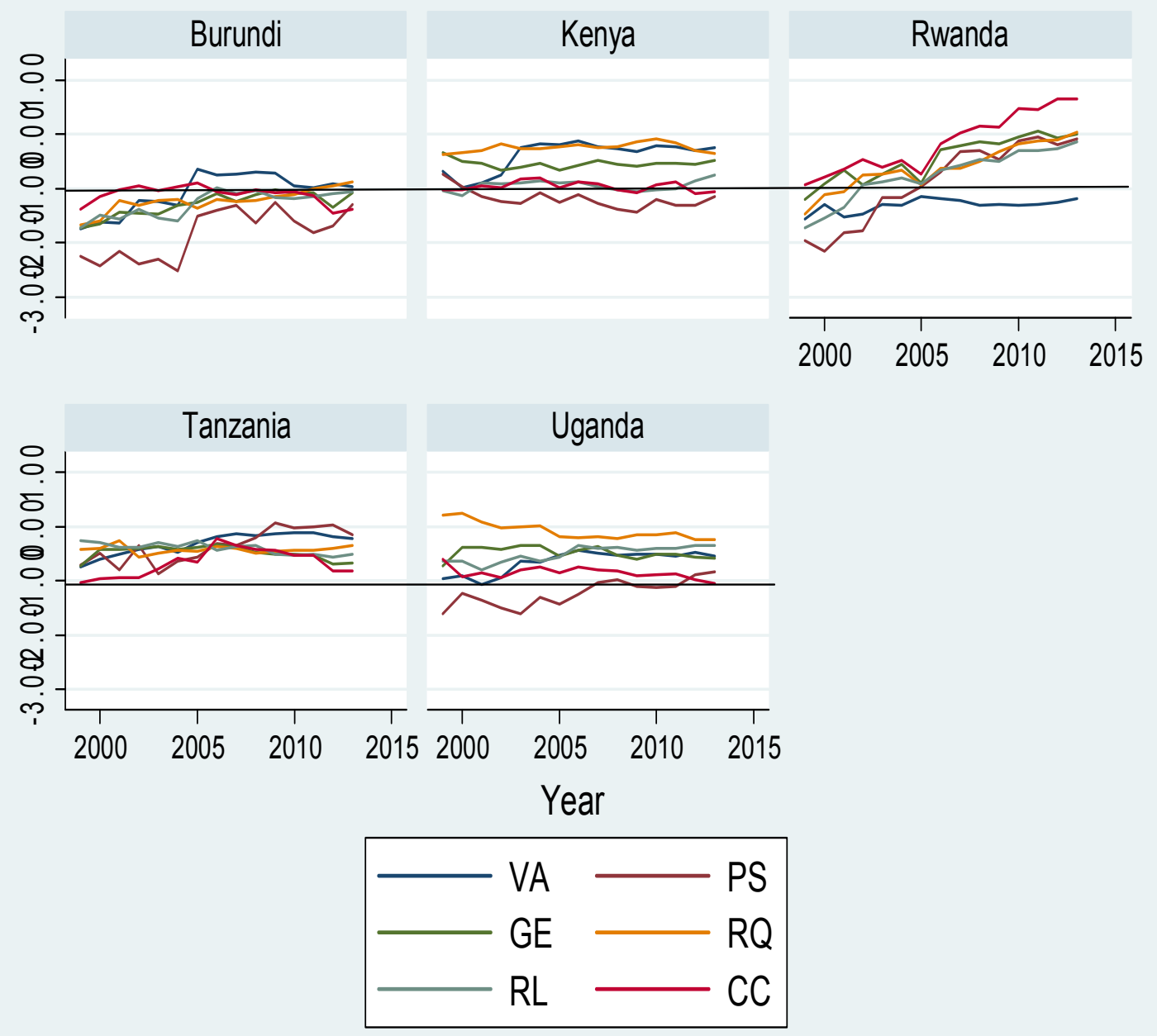

Graphs by Countrycode

Figure 3. Trends in Governance Indices per country 


\subsection{Effects of Governance Indices on Economic Growth in EAC Countries}

Good governance has been quite emphasized by both theoretical and empirical literatures. It is suggested that good governance is the foundation of economic growth. This objective therefore intends to identify specific governance indices, social and macroeconomic factors that may foster general economic growth in EAC countries. Through descriptive statistics, we observed how variations across panels and among the parameters elucidate that predisposition. In this objective, we were interested in exploring how the said variables with their stochastic nature relate with economic growth in both countries. The conceptualized model was estimated by Random Effects GLS model with pre-estimation of multicollinearity test, unit roots and Hausman specification test.

\subsection{Multicollinearity Test}

Multicollinearity is considered to exist when there is perfect linear relationship between the variables under the study. The variance inflation factors were used to determine if any pair of independent variables was highly collinear and the size and magnitude of the pairs of variables determined by the correlation matrix. For VIF values greater than 10 and 1/VIF values less than 0.10 Multicollinearity is deemed to be present.

Table 2. VIF

\begin{tabular}{lllll}
\hline Variable & $\begin{array}{l}\text { VIF before first } \\
\text { differencing }\end{array}$ & $\begin{array}{l}\text { 1/VIF before } \\
\text { differencing }\end{array}$ & $\begin{array}{l}\text { first } \\
\text { VIF } \\
\text { first } \\
\text { differencing }\end{array}$ & $\begin{array}{l}\text { after } \\
\text { differencing }\end{array}$ \\
\hline GE & 40.91 & 0.024443 & 1.81 & 0.552045 \\
PS & 27.34 & 0.036573 & 1.42 & 0.705146 \\
GFCRATE & 26.86 & 0.037234 & 1.35 & 0.738578 \\
OPEN & 25.90 & 0.038610 & 1.32 & 0.760148 \\
RL & 24.10 & 0.041500 & 1.86 & 0.537485 \\
RQ & 14.35 & 0.069672 & 1.47 & 0.680292 \\
CC & 13.79 & 0.072498 & 1.49 & 0.670795 \\
POPRATE & 12.74 & 0.078507 & 1.41 & 0.708480 \\
VA & 7.57 & 0.132157 & 1.69 & 0.592892 \\
INF & 4.24 & 0.235688 & 1.24 & 0.808403 \\
Mean VIF & 19.78 & & 1.51 & \\
\hline
\end{tabular}

Source: Authors' calculations.

Table 2 shows that GFC rate, OPEN, POP rate and all governance indicators except Voice and accountability had high correlation implying presence of Multicollinearity. However, upon first differencing, Multicollinearity was reduced.

\subsection{Unit root test}

Table 2 below shows the test result and it was revealed that all variables had the palues greater than 0.05 which led to non-rejection of the null hypothesis (that the variables had unit root). Therefore, the first differences were conducted in an attempt to correct for non 
stationarity.

Table 3. Unit root tests

\begin{tabular}{|c|c|c|c|c|c|}
\hline Variables & $\begin{array}{l}\text { Unadjusted } \\
\text { statistic }\end{array}$ & $\begin{array}{ll}\mathbf{P} \quad \text { value } \\
\operatorname{lag}(0)\end{array}$ & at & $\begin{array}{l}\text { Unadjusted } t \\
\text { statistic after } 1^{\text {st }} \\
\text { differencing }\end{array}$ & $\begin{array}{l}\text { P value at lag (0) } \\
\text { after } \\
\text { differencing }\end{array}$ \\
\hline GDP RATE & -2.9054 & 0.07143 & & -12.1022 & 0.0000 \\
\hline $\mathbf{V A}$ & -3.9829 & 0.0598 & & -10.8510 & 0.0000 \\
\hline PS & -4.6042 & 0.05113 & & -9.4529 & 0.0000 \\
\hline GE & -0.0721 & 0.8712 & & -6.8043 & 0.0017 \\
\hline RQ & -3.2636 & 0.1011 & & -11.4714 & 0.0000 \\
\hline $\mathbf{R C}$ & -1.9194 & 0.1224 & & -10.4633 & 0.0000 \\
\hline $\mathrm{CC}$ & -2.6824 & 0.1013 & & -10.9616 & 0.0000 \\
\hline POPRATE & -0.3509 & 0.2052 & & -9.5902 & 0.0000 \\
\hline GFCRATE & -4.6563 & 0.1236 & & -9.4676 & 0.0000 \\
\hline INF & -2.9957 & 0.3201 & & -12.7068 & 0.0000 \\
\hline OPEN & -3.1376 & 0.0632 & & -9.7350 & 0.0000 \\
\hline
\end{tabular}

Source: Authors' computation.

\subsection{Fixed Effects versus Random Effects Model}

Consequently, on conducting the test, it was shown that P-value of 0.8854 implied that the individual level effects are best modelled using the random effects method.

Table 4. Hausman specification test

\begin{tabular}{lllll}
\hline Variables & $\begin{array}{l}\text { Coefficients of Fixed } \\
\text { Effects (F) }\end{array}$ & $\begin{array}{l}\text { Coefficients of } \\
\text { Random Effects (R) }\end{array}$ & $\begin{array}{l}\text { Difference } \\
(\text { F-R) }\end{array}$ & S. Error \\
\hline DVA & -3.196988 & -2.459576 & -0.7374119 & 0.4558133 \\
DPS & -3.750682 & -3.750753 & 0.0000717 & 0.368649 \\
DGE & -3.835574 & -3.455299 & -0.3802755 & 0.2111949 \\
DRQ & -7.921395 & -6.810586 & -1.110809 & 1.192318 \\
DRL & 5.765365 & 4.60532 & 1.160045 & 1.330086 \\
DCC & 7.676853 & 6.999353 & 0.6775001 & 0.5196623 \\
DPOPRATE & -1.173894 & -1.199167 & 0.0252738 & 0.0193365 \\
DGFCRATE & -0.1658724 & -0.1239902 & -0.0418822 & 0.040378 \\
DINF & -0.1426529 & -0.1515121 & 0.0088592 & 0.0059758 \\
DOPEN & 0.1067099 & 0.1132393 & -0.0065295 & 0.0093416 \\
Chi2(10) $=\mathbf{5 . 0 9 ;}$ Prob $>$ chi2 $=\mathbf{0 . 8 8 5 4}$ & & & \\
\hline
\end{tabular}

$\mathrm{H}_{\mathrm{o}}$ : Difference in Coefficients not systematic

In this study, the Hausman test preferred random effects model to fixed effects model which allows estimation effects of the mean of the distribution effects rather than estimating one true effect. Since each country represented in our study provides varied information about a different effect size, we thus had to ensure that all these effects size are represented in the 
summary estimate. According to Borenstein (2009), preference of the Random Effects, implies that we had to estimate the mean effect in the five countries. Under the random effects, the null hypothesis tested is that the mean effect is zero.

\subsection{Results for Random Effects GLS and OLS Models}

The adoption of random effects model was based on different countries which may not have shared the common effect size in terms of economic growth and the core objective of establishing the contribution of governance to economic growth. Similarly, OLS results are shown for the respective countries. As indicated in Table 5, the total variations explaining the economic growth in the EAC countries were $51.65 \%$ while the other proportion may have been factored in by other factors not considered by this study. Also, $50.64 \%$ of the variations explain economic growth in between the panels while $54.44 \%$ of the variations explain the economic growth within the panels. The overall regression fit is significant. This is because the overall $\mathrm{P}$ value of REM (0.0000) is less than 0.05 . The standard deviation of residuals between groups is 2.6546 (sigma_e). Therefore there is no correlation between the error terms and the regressors. The OLS estimates had an R squared ranging between $84.12 \%$ and $95.32 \%$ which is a good proportion showing that most variables actually explained economic growth in the respective countries. However, all countries had an overall significance of $5 \%$ except Rwanda which had an overall significance of $6.63 \%$ slightly higher than $5 \%$ implying the variables explaining dependent variables were significant at $10 \%$ level.

Table 5. REM and OLS model for all countries

\begin{tabular}{|c|c|c|c|c|c|c|c|c|c|c|c|c|}
\hline \multirow{3}{*}{$\begin{array}{l}\text { Countries } \\
\text { Economic } \\
\text { Growth }\end{array}$} & \multicolumn{2}{|c|}{$\begin{array}{l}\text { ALL EAC Countries } \\
\text { (REM) }\end{array}$} & \multicolumn{2}{|c|}{$\begin{array}{l}\text { Burundi } \\
\text { (OLS) }\end{array}$} & \multicolumn{2}{|c|}{$\begin{array}{l}\text { Kenya } \\
\text { (OLS) }\end{array}$} & \multicolumn{2}{|c|}{$\begin{array}{c}\text { Rwanda } \\
\text { (OLS) }\end{array}$} & \multicolumn{2}{|c|}{$\begin{array}{c}\text { Tanzania } \\
\text { (OLS) }\end{array}$} & \multicolumn{2}{|c|}{$\begin{array}{l}\text { Uganda } \\
\text { (OLS) }\end{array}$} \\
\hline & Robust & t-statistics & Robust & t-statistics & Robust & t-statistics & Robust & t-statistics & Robust & t-statistics & Robust & t-statistics \\
\hline & \multicolumn{2}{|l|}{ Coefficients } & \multicolumn{2}{|c|}{ Coefficients } & \multicolumn{2}{|c|}{ Coefficients } & \multicolumn{2}{|c|}{ Coefficients } & \multicolumn{2}{|c|}{ Coefficients } & \multicolumn{2}{|c|}{ Coefficients } \\
\hline DVA & -2.46 & -0.89 & -14.60 & -0.49 & $8.81 * * *$ & 3.20 & -6.78 & -0.14 & -0.73 & -0.18 & $-18.76^{* *}$ & -2.28 \\
\hline DPS & $-3.75^{* *}$ & -2.48 & -2.92 & -0.34 & 3.97 & 1.55 & -14.54 & -0.49 & -1.86 & -0.94 & -1.99 & -0.30 \\
\hline DGE & -3.46 & -1.22 & -24.12 & -0.77 & 2.29 & 0.41 & -2.00 & -0.04 & -5.18 & -0.45 & -0.61 & -0.12 \\
\hline DRQ & $-6.81^{* *}$ & -2.07 & -13.93 & -0.44 & $-10.66^{*}$ & -1.84 & -25.85 & -0.66 & $-9.61 * * *$ & -4.68 & 1.71 & 0.15 \\
\hline DRL & 4.61 & 1.34 & 18.75 & 1.05 & $-10.74 * * *$ & -5.58 & 25.74 & 1.13 & -4.75 & -0.68 & 19.03 & 1.21 \\
\hline DCC & $7.00^{* * *}$ & 2.79 & 22.35 & 0.90 & 2.84 & 0.42 & 7.78 & 0.35 & 1.67 & 0.50 & 11.08 & 1.40 \\
\hline DPOPRATE & $-1.20 * * *$ & -3.07 & 0.20 & 0.02 & -19.57 & -1.51 & -0.86 & -0.20 & 2.53 & 0.34 & $9.18^{* * *}$ & 2.93 \\
\hline DGFCRATE & -0.12 & -0.86 & -0.56 & -0.77 & 0.62 & 1.02 & -0.10 & -0.03 & $0.42 * * *$ & 2.94 & -0.22 & -0.21 \\
\hline DINF & $-0.15^{* * *}$ & -3.73 & -0.089 & -0.59 & $-0.25^{* * *}$ & -3.51 & 0.01 & 0.01 & $-0.17^{*}$ & -1.83 & -0.11 & -1.44 \\
\hline DOPEN & $0.11^{*}$ & 1.75 & 0.35 & 0.70 & 0.19 & 1.13 & 0.48 & 0.79 & -0.06 & -1.16 & 0.05 & 0.35 \\
\hline Constant & 0.15 & 0.40 & 2.55 & 0.96 & -0.45 & -0.94 & 0.27 & 0.09 & -0.61 & -1.78 & 0.55 & 0.90 \\
\hline No. & & & & & & & & & & & & \\
\hline \multicolumn{13}{|l|}{ Observations } \\
\hline Wald & 63.03 & & 9.17 & & 90.02 & & 7.39 & & 13.47 & & 25.79 & \\
\hline \multicolumn{13}{|l|}{ Chi2(10)/F(10, } \\
\hline 3) & & & & & & & & & & & & \\
\hline
\end{tabular}




\begin{tabular}{|c|c|c|c|c|c|c|}
\hline \multirow[t]{2}{*}{ R-Squared } & Overall $=0.5165$ & 0.8656 & 0.9532 & 0.8412 & 0.9122 & 0.8500 \\
\hline & $=0.5064$ & & & & & \\
\hline Prob $>$ Chi2 & 0.0000 & 0.0471 & 0.0017 & 0.0633 & 0.0275 & 0.0108 \\
\hline Root MSE & - & 3.7527 & 0.95852 & 4.4683 & 0.55722 & 2.162 \\
\hline
\end{tabular}

Consider; */**/*** significant coefficients at $10 \%, 5 \%$ and $1 \%$ levels respectively.

Source: Authors' calculation based on the available data.

\section{Discussion of the findings; Comparative analysis between REM and OLS}

Upon specifying the random effects model, the findings are ready for discussion. The study explored significant factors as indicated by Table 5 above; it was revealed that if all other factors were kept constant, voice and accountability significantly increased economic growth in Kenya by $8.81 \%$ and lower Uganda's economic growth rate by $18.76 \%$ respectively. The REM was not significant at all levels. Also, Burundi, Rwanda and Tanzania had no significant influence of voice and accountability on economic growth. Secondly, political stability and absence of violence was shown to lower economic growth rate of all EAC countries collectively with no significant effect on any country under study (OLS models were insignificant). Considering REM, it was found that a unit change in political stability and absence of violence, led to a lower economic growth rate of EAC by $3.75 \%$. This implies that economic growth declines as destabilization of the government by unconstitutional or violent means increases. Therefore there is a negative and significant relationship between political stability and economic growth. This result is similar to the findings obtained by Chong and Calderon (2000) who examined the impact of political institutions on income inequality for One hundred and twenty one countries classified as both developing and industrial countries using the six indicators from the world governance Indicators data set and ICRG civil liberties and political rights indices. They found out that political considerations and the political stability indicator hugely influences inequality aspects which made the authors conclude that poor institutions and income inequality reinforce each other.

There was established significant and negative relationship between quality of regulation and economic growth among East Africa countries. This significant effect was observed specifically in Kenya and the Republic of Tanzania. As the ability of government(s) in East Africa strives to develop and implement sound policies and regulations conducive to private sector development, economic growth rate declines contrary to our expectations. From the estimation, the REM revealed that as quality of regulation improves, economic growth rate declines by $6.81 \%$ holding other factors constant while OLS indicates growth rates for Kenya and Tanzania declining at $10.66 \%$ and $9.61 \%$ respectively holding other factors constant. By comparing an aggregated governance measure calculated from the six governance indicators against per capita real income, Quibria (2006) found that quality of regulation was ranked third with high correlation with per capita real GDP. This was revealed as the authors were conducting a related study to validate the governance and growth relationship in Asia, they estimated the governance surplus or deficit for each developing Asian economy. Contrary to our study findings, both of these ranked indicators had a positive relationship with per capita real GDP. The OLS model indicated a significant effect of rule of law on economic growth rate 
only in Kenya.

Specifically, the study found that improved rule of law led to a lower economic growth by $10.74 \%$ holding other factors constant. In other countries it was not significant. This may be attributed to consequent regulation of illegal activities and resources which enter the economy in this case Kenya which influences economic growth. Lastly, the REM revealed a positive and significant relationship between control for corruption and economic growth rate. Increase in controlled level of corruption increases economic growth rate approximately by $7 \%$ holding other factors constant. Azfar and Gurgur (2005) undertook a similar study among communities in the Philippines where they analysed corruption levels and obtained valuable information on how corruption levels impact on development. Their findings concurred with the study findings in this paper as they established that communities with higher levels of perceived corruption experienced worse health and education indicators which ultimately impacted economic development negatively. This implies that as the use of public positions for private gain, including petty and grand corruption, as well as the elite and private interests taking the state hostage is lowered to manageable levels, better business environment is created and thus economic growth rate.

\section{Conclusions and Recommendations}

Upon reviewing diverse literature the study concurred on the dimensions and in particular, how good governance is linked with government's structures, processes they use in governing, results they are able to accomplish for the economy and the people they govern. The study revealed that economic growth rate was significantly influenced by political stability, quality of the regulation and control of corruption as governance indicators contributed significantly to economic growth rate in REM. On the other hand, OLS indicated interesting results. For example; voice and accountability had a significant effect on economic growth rate in Kenya and Uganda; quality of regulation was found to have a significant effect in Kenya and Tanzania while rule of law was found to be significant only in the case of Kenya. Despite the fact that good governance forms the core framework of fiscal prudence, this study concludes that for consistent economic growth of state, there is a need for proper utilization of resources in public domain and a respective accountable system.

The role of governance as a factor for economic growth is well founded in the economic growth models majorly attributed to Institutional Economists. It is argued that good governance attracts investors by creating an environment that is conducive and this boosts employment. Further, good governance leads to efficiency and effective processes, promotes accountability and transparency, reduced red tape and bureaucracy and overall promotes productivity. Based on the study findings, poor regulation consequently leads to decline in economic growth. Therefore, governments need to re examine the existing institutions and how they link with governance. In addition institutional structures should be reorganized in a manner likely to shape diverse interactions leading to increase in economic activities and thus overall growth. The reorganization could be social, economic or political. These could then guide the policies likely to be chosen and implemented to enable sustainability. This will ensure EAC states are eligible in receiving foreign aid or donor support, due to better conducive environment which could also encourage and increase confidence from both local 
and foreign investors.

Political stability should be enhanced through fostering national cohesion among the inhabitants of a nation. It should also be acknowledged that in addition to the estimated significant results, the EAC states have diverse cultures which could be a recipe for violence if not well managed as was the case during the post-election violence experienced in Kenya in $2007 / 2008$. Systematic management of conflict between the political rulers and the society which incorporates institutions that guarantee maximization of the welfare of the political elite at the expense of the society will raise economic development. Therefore, as a region, there is need to improve key governance institutions through advocacy of reforms in public institutions and promotion of laws intended to foster good governance. Public sector reforms have a significant impact on the overall fiscal management of the economy.

\section{References}

Akpan, G. E., \& Effiong, E. L. (2012). Governance and development performance: a cross-country analysis of Sub-Saharan Africa. Journal of Economics and Sustainable Development, 3(14), 54-65.

Azfar, O., \& Gurgur, T. (2005). Does corruption affect health and education outcomes in the Philippines?

Borenstein, M., Hedges, L. V., Higgins, J. P. T., \& Rothstein, H. R. (2009). Front Matter, in Introduction to Meta-Analysis. John Wiley \& Sons, Ltd, Chichester, UK. http://dx.doi.org/10.1002/9780470743386.fmatter.

Bouoiyour, J., \& Naimbayel, D. (2012). Economic growth in Sub-Saharan Africa: is governance a source of inequality between countries? In A Paper presented at the 17th Annual Conference of the African Econometric Society. JEL Classification: C-33, O-40, O-43.

Bräutigam, D. A., \& Knack, S. (2004). Foreign aid, institutions, and governance in sub-Saharan Africa. Economic Development and Cultural Change, 52(2), 255-285. http://dx.doi.org/10.1086/380592

Chauvet, L., \& Collier, P. (2004). Development effectiveness in fragile states: Spillovers and turnarounds. Centre for the Study of African Economies, Department of Economics, Oxford University. Retrieved from http://www.jica.go.jp/cdstudy/library/pdf/20071101_09.pdf

Chong, A., \& Calderon, C. (2000). Causality and feedback between institutional measures and economic growth. Economics \& Politics, 12(1), 69-81. http://dx.doi.org/10.1111/1468-0343.00069

Cooray, A. (2009). Government expenditure, governance and economic growth. Comparative Economic Studies, 51(3), 401-418. http://dx.doi.org/10.1057/ces.2009.7

Fayissa, B., \& Nsiah, C. (2010). The impact of governance on economic growth: further evidence for Africa. Middle Tennessee State University Department of Economics and Finance Working Paper Series. Retrieved from https://www.researchgate.net/profile/Christian_Nsiah2/publication/265723317_The_Impact_ 
of_Governance_on_Economic_Growth_in_Africa/links/09e4150fdced78d03c000000.pdf

Greene, W. H. (2008). The econometric approach to efficiency analysis. The measurement of productive efficiency and productivity growth, 92-250. http://dx.doi.org/10.1093/acprof:oso/9780195183528.003.0002.

Hall, R. E., \& Jones, C. I. (1999). Why do some countries produce so much more output per worker than others? (No. w6564). National bureau of economic research. http://dx.doi.org/10.3386/w6564

Kagundu, P. (2006). The Quality of Governance, Composition of Public Expenditures, and Economic Growth: An Empirical Analysis. Retrieved from http://scholarworks.gsu.edu/econ_diss/13/

Kaufmann, D., \& Kraay, A. (2003). Governance and Growth: Causality which way? Evidence form the World, in brief. Manuscript. World Bank publication. Retrieved from http://siteresources.worldbank.org/INTWBIGOVANTCOR/Resources/growthgov_synth.pdf

Kaufmann, D., Kraay, A., \& Mastruzzi, M. (2009). Governance matters VIII: aggregate and individual governance indicators, 1996-2008. World Bank policy research working paper, (4978).

Retrieved

from https://openknowledge.worldbank.org/bitstream/handle/10986/4170/WPS4978.pdf?sequence $=1$

Kaufmann, D., Kraay, A., \& Zoido, P. (1999). Governance matters. World Bank policy research working paper, (2196). World Bank. Retrieved from http://papers.ssrn.com/sol3/papers.cfm?abstract_id=188568

King, R., \& Rebelo, S. (1990). Public policy and economic growth: developing neoclassical implications (No. w3338). National Bureau of Economic Research. http://dx.doi.org/10.3386/w3338

Knack, S., Kugler, M., \& Manning, N. (2003). Second-generation governance indicators. International Review of Administrative Sciences, 69(3), 345-364. http://dx.doi.org/10.1177/0020852303693004

Ndulu, B., \& O'Connell, S. (1999). Governance and Growth in Sub-Saharan Africa. The Journal of Economic Perspectives, 13(3), 41-66. Retrieved from http://www.jstor.org/stable/2646984

North, D. (1990). Institutions, Institutional Change and Economic Performance. Cambridge, New York: Cambridge University Press.

North, D. C. (2005). Institutions and the process of economic change. Management International, 9(3), 1-7.

Pritchett, L. (1996). Mind your P's and Q's: the cost of public investment is not the value of public capital. World Bank Policy Research Working Paper, (1660).

Quibria, M. G. (2006). Does governance matter? Yes, no or maybe: Some evidence from 


\section{Macrothink}

International Journal of Regional Development

ISSN 2373-9851

2016, Vol. 3, No. 2

developing Asia. Kyklos, 59(1), 99-114. http://dx.doi.org/10.1111/j.1467-6435.2006.00322.x

Rajkumar, A. S., \& Swaroop, V. (2008). Public spending and outcomes: Does governance matter? Journal of Development Economics, 86, 96-111. http://dx.doi.org/10.1016/j.jdeveco.2007.08.003

Rowley, C. K. (1999). Rent seeking and rent extraction from the perspective of Africa. In M. S. Kimenyi \& J. M. Mbaku (Eds.), Institutions and collective choice in developing countries: applications of the theory of public choice (pp. 233-254). Aldershot, UK and Brookfield, VT, USA: Ashgate

World Bank Group (Ed.). (2012). World Development Indicators 2012. World Bank Publications.

\section{Copyright Disclaimer}

Copyright for this article is retained by the author(s), with first publication rights granted to the journal.

This is an open-access article distributed under the terms and conditions of the Creative Commons Attribution license (http://creativecommons.org/licenses/by/3.0/). 